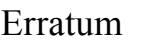

\title{
Erratum to: Decontamination of Chemical Warfare Agents by Novel Oximated Acrylate Copolymer
}

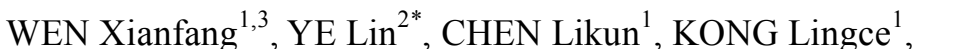

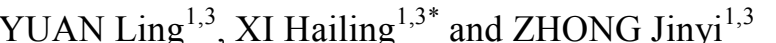

1. State Key Laboratory of NBC Protection for Civilian, Beijing 102205, P. R. China;

2. School of Material Science and Engineering, Beijing Institute of Technology, Beijing 100081, P. R. China;

3. Research Institute of Chemical Defense, Beijing 102205, P. R. China

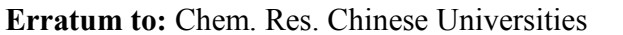

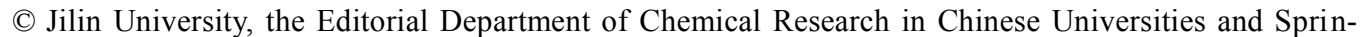

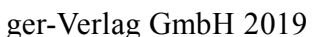

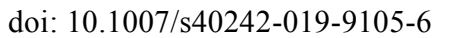

$\square$

$\square$

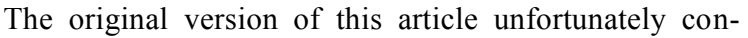

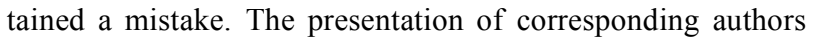

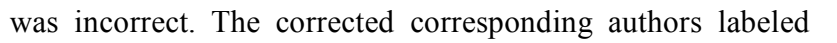

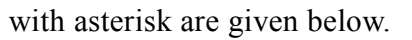

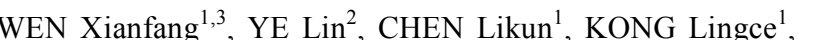

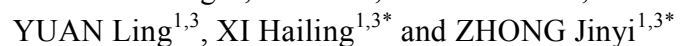

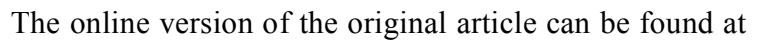

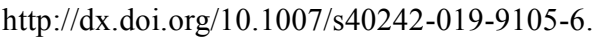

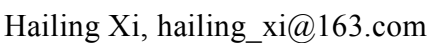

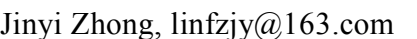

